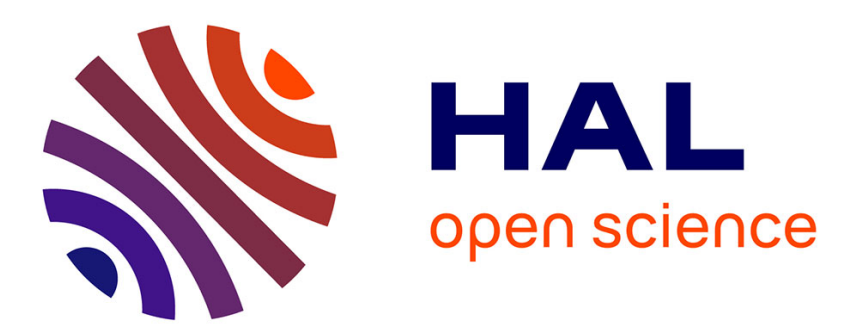

\title{
Transient fluvial landscape and preservation of low-relief terrains in an emerging orogen: Example from Hengchun Peninsula, Taiwan
}

\author{
S. Giletycz, Nicolas Loget, C.P. Chang, Frédéric Mouthereau
}

\section{- To cite this version:}

S. Giletycz, Nicolas Loget, C.P. Chang, Frédéric Mouthereau. Transient fluvial landscape and preservation of low-relief terrains in an emerging orogen: Example from Hengchun Peninsula, Taiwan. Geomorphology, 2015, 231, pp.169-181. 10.1016/j.geomorph.2014.11.026 . hal-01109390

\author{
HAL Id: hal-01109390 \\ https://hal.science/hal-01109390
}

Submitted on 26 Jan 2015

HAL is a multi-disciplinary open access archive for the deposit and dissemination of scientific research documents, whether they are published or not. The documents may come from teaching and research institutions in France or abroad, or from public or private research centers.
L'archive ouverte pluridisciplinaire HAL, est destinée au dépôt et à la diffusion de documents scientifiques de niveau recherche, publiés ou non, émanant des établissements d'enseignement et de recherche français ou étrangers, des laboratoires publics ou privés. 


\section{Transient fluvial landscape and preservation of low-relief}

\section{2 terrains in an emerging orogen: example from Hengchun}

\section{Peninsula, Taiwan}

5 S. Giletycz ${ }^{1}$, N. Loget ${ }^{2,3}$, C-P. Chang ${ }^{1,4}$, F. Mouthereau ${ }^{2,3,5,{ }^{*}}$

7 Affiliation

$8{ }^{1}$ Institute of Geophysics, National Central University, Chungli 320, Taiwan

$9 \quad{ }^{2}$ Sorbonne Universités. UPMC Univ Paris 06, UMR 7193, Institut des Sciences de la

10 Terre Paris (iSTeP), 4 Place Jussieu, F-75005 Paris, France

$11{ }^{3}$ CNRS, UMR 7193, Institut des Sciences de la Terre Paris (iSTeP), 4 Place Jussieu, F-

1275005 Paris, France

$13{ }^{4}$ Geological Remote Sensing Laboratory, Center for Space and Remote Sensing

14 Research, National Central University, Chungli 320, Taiwan

$15 \quad{ }^{5}$ Laboratoire International Associé ADEPT, CNRS-NSC

16 * Now at Université Toulouse III - Paul-Sabatier, Laboratoire Geoscience Environment

17 de Toulouse, UMR 5563, 14 av. Edouard Belin, F-31400 Toulouse, France

19 Corresponding author:

20 Slawomir Jack Giletycz 
21 Department of the Earth Sciences, National Central University; address: Chongda

22 Road, 300, Chungli, Taoyuan County, Taiwan ROC; tel: (03) 4227151 ext. 57671;

23 email: geojack.slawek@gmail.com

24

25

26

27

28 


\section{Abstract}

31 The oblique collision of Taiwan orogen led to a progressive southward uplift and

32 emergence of a submarine accretionary wedge. The Hengchun Peninsula located at

33 the southernmost tip of Taiwan island represents the most recently emerged

34 landform of an antecedent submarine surface. In this study we examine the

35 geomorphic evolution of this newly emerged and uplifted landscape. The extraction

36 of geomorphic parameters (knickpoints distribution, steepness index of rivers)

37 indicates a transient nature of the landscape but shows that a simple model of

38 regressive erosion consecutive to sudden uplift is unsatisfactory. Knickpoints

39 migration modeling shows that only the upstream Sizhong basin can be explained

40 by this single process. On the other hand, the occurrence of a relict landscape

41 (Mutan Ponds low-relief) developed at low elevations, and today uplifted in the core

42 of the peninsula, has strongly influenced the drainage evolution. Numerous

43 knickpoints are linked to capture processes around the Mutan Ponds area,

44 indicating a dynamic reorganization of the drainage system. We propose that the

45 landscape of the Hengchun Peninsula is in a transient stage and results from a

46 combination between rejuvenation and drainage rearrangement caused by the late

47 stage of emergence of the south of Taiwan.

48

49

50

51 
53 Key words: transient landscape, orogen, Taiwan, fluvial processes, knickpoint 54 retreat

55 


\section{1. Introduction}

58 The early stage of fluvial landscape development associated with emerging

59 mountain ranges is often difficult to capture in natural systems. First, this is because

60 the juvenile geomorphic surfaces need to be unambiguously distinguished from

61 former submarine processes that shaped the landscape. Second, they are basically

62 transient and therefore the rate at which this landscape is preserved directly

63 depends on tectonic forcing and prevailing erosional processes (Burbank, 2002).

64 Better understanding of these processes as well as the time response of landscape to

65 tectonics or climate in active areas requires an approach that aimed at quantifying

66 the early stages of geomorphic development (Willett and Brandon, 2002; Whipple,

67 2004; Crosby and Whipple, 2006; Garcia-Castellanos, 2006; Ramsey, 2006;

68 Whittaker et al., 2007; Craddock et al., 2010; Walker et al. 2011).

69 Taiwan is classically described as an active orogenic system that reached a steady-

70 state (Whipple, 2001) and where transient stages of landscape development are

71 expected to be hardly preserved. However, due to convergence obliquity that

72 induces uplift to propagate southwards (Suppe, 1981; Willett et al., 2003), the

73 southern tip of Taiwan appears to be ideally located to assess the role of outboard

74 marine inherited landscape and the geomorphic processes at play during the initial

75 stage of mountain building (Fig. 1). Previous studies in central Taiwan have shown

76 that topographic steady-state can be reached where high erosion rates $2-5 \mathrm{~mm} / \mathrm{yr}$

77 are recorded (Willett et al. 2003; Siame et al. 2011). However, in contrast to the

78 northern and more mature part of the mountain belt, the Hengchun Peninsula in the 
79 south is characterized by low erosion rates as indicated by old, pre-orogenic fission-

80 track ages (Fuller et al., 2006), indicating this region did not reach an exhumational

81 steady-state. Transient stages of landscapes are mostly characterized by knickpoints

82 in their river profiles linked to a base-level drop or an increase of the tectonic uplift

83 (Whipple and Tucker, 1999; Bishop et al., 2005; Loget et al., 2006; Whittaker, 2007;

84 Attal et al., 2008; Gallen et al., 2013). Numerous works have attempted either to

85 calibrate erosional models or extract tectonic information from river profiles but in

86 most of cases they start from an inherited continental domain or antecedent

87 drainage systems (e.g., Roberts and White, 2010). Few works concern the

88 adaptation and organization of a drainage system following a large and recent

89 emerging domain (e. g., Rosenbloom and Anderson, 1994). A coupled approach of

90 river incision and organization/reorganization could be used as a marker of the

91 dynamic of emergence of continental domains.

92 In this paper, we examine the landscape evolution of the Hengchun Peninsula where

93 transient geomorphic processes, including patterns of drainage reorganization

94 (capture, knickpoints/knickzones) and relicts of low-relief high-elevation areas are

95 present. We first detailed the main geomorphic features of the peninsula

96 characterized by a N-S low-relief area pinned along the western side of the main

97 divide that are incised successively with time by the western and eastern flanks,

98 respectively. We then discuss on the origin of the main knickpoints positioned

99 around the low-relief area using a knickpoint celerity modeling approach and

100 steepness index maps. Geomorphological analyses of the large drainage basins of

101 the Hengchun Peninsula reveal that river channels recorded recent dynamics of the 
102 youngest Taiwan orogen. We show that a simple rejuvenation stage cannot explain

103 the main geomorphic features. A mixed model of knickpoint propagation and

104 drainage rearrangement with captures caused by the late stage of emergence of the

105 peninsula is proposed. These erosive and landscape evolution patterns appear to be

106 compatible with an uplift originated from a deep crustal block related. The recent

107 uplift in the Hengchun Peninsula is caused by the continuing progression of the

108 collision towards the south of Taiwan.

109

\section{2. Geological background}

111 The Taiwan arc-continent collision is the result of the convergence between the

112 Chinese continental margin of the Eurasian plate and the Luzon arc belonging to the

113 oceanic Philippine Sea plate (Fig. 1). Collision started 6.5 Ma as inferred from initial

114 orogenic loading in western Taiwan (Lin et al., 2003) and onset of cooling, above the

115 underthrust continental crust, recorded at 7.1 Ma by low-temperature

116 thermochronological data (Mesalles et al., 2014). The emergence of the mountain

117 belts and coupling with surface processes become efficient after 5 Ma in northern

118 Taiwan and not before 3.5 Ma in southern Taiwan (Mesalles et al., 2014). Unreset

119 apatite fission-track ages in southernmost Central Range and Hengchun Peninsula

120 (Fuller et al., 2006; Simoes et al., 2012; Mesalles et al., 2014) argue for a slower or

121 more recent exhumation in the region with respect to the northern Taiwan. Overall,

122 these constraints are consistent with the obliquity of the convergence, implying that

123 collisional uplift and exhumation in southern Taiwan is the most recent. 
124 The southward propagating model places the Hengchun Peninsula as the most lately

125 emerged region in Taiwan. As a result, the evolution of the fluvial landscape is also

126 probably the most recent, but it is yet to be determined. In particular, the patterns of

127 river captures and regressive erosion along river trunk streams have never been

128 described, thus precluding further quantification of geomorphic processes.

129 The peninsula comprises folded, non metamorphic or slightly metamorphosed,

130 Middle to Late Miocene sandstones and siltstones (Fig. 2). They correspond to

131 turbiditic sequences characterized by slope gravitational instabilities sedimentary

132 features. Lenticular conglomeratic bodies with channeling forms are locally

133 abundant and can be easily identify in the landscape due to their rough topography

134 (see Fig. 2, Shimen conglomerates). They are composed of reworked Miocene

135 sandstones, basalt, gabbros and ultramafic rocks (Pelletier and Stephan, 1986). Two

136 other sandstone members can be distinguished on the northwest and southeast tips

137 of the peninsula. Adjacent to the Miocene formation, to the west, there is the Kenting

138 ophiolitic Mélange (Kenting Formation of Fig. 2), interpreted as sheared and locally

139 faulted tectonic mélange that developed from the Late Miocene to Plio-Pleistocene.

140 The studied area is the onshore equivalent of southern accretionary prism. Its uplift

141 and exhumation appear to be driven by the accretion of a transitional crust

142 composed of the extremely-thinned continental basement of the South China Sea

143 that is tectonically stacked with Miocene post-rift deposits (McIntosh et al., 2013).

144 Well-developed Holocene marine terraces containing abundant remnants of corals

145 are found along the southern and southwestern coasts of the peninsula (Lee and

146 Liew and Lin, 1987; Chen and Liu, 1993) (Fig. 2) uplifted from few to 40 meters 
147 above the sea level. Their radiocarbon dating gives ages of 10 kyr suggesting mean

148 uplift around $3.5 \mathrm{~mm} / \mathrm{yr}$ during Holocene (e.g. Wang and Burnett, 1990). Coral

149 platforms corresponding to Hengchun Limestone are also observed on 200-meter

150 high cliffs of the southwestern part of the Hengchun Peninsula- Hengchun Hill

151 (Cheng and Huang, 1975; Chen and Lee, 1990)(see Fig. 2, Hengchun Limestone).

152 Their ages are estimated around Late Pleistocene ( $\sim 100 \mathrm{ky})$ suggesting mean uplift

153 rates around 3-4 mm/y during Pleistocene. Few recent ages are published more

154 inland and only lacustrine deposits in Mutan Ponds low reliefs gives an age of

155 deposition between 2 and 20 ky (Yang et al., 2011). Synchronism of inland

156 lacustrine sediments and the uplifts of the Holocene marine terraces argue that the

157 uplifts of the marine terraces along the coasts could impact the deposition of the

158 Mutan Ponds within the drainage basins of the Hengchun Peninsula.

160 3. Geomorphic characteristics of the Hengchun Peninsula

161 In Taiwan, a combination of very humid and monsoonal climate coupled with active

162 tectonics causes rapid fluvial erosion forming high-relief terrains and unstable

163 slopes (Fuller et al., 2006; Ramsey et al., 2007; Giletycz et al., 2012). Heterogeneous

164 character of the rock strength or uplift results in local preservation of

165 geomorphological patterns. This particular setting gives us the opportunity to

166 examine the response of fluvial processes and landscape adjustment to short-

167 term/transient acceleration of subsurface deformations. Previous studies on Taiwan

168 geomorphology show that drainage systems ultimately control the regional

169 denudation and shape the orogen (Whipple, 2001; Wobus et al. 2006; Ramsey, 
170 2006; Ramsey et al. 2007; Stolar et al. 2007). For example, Stolar et al. (2007)

171 suggested that tectonic perturbations are balanced by channel response along the

172 eastern Central Range. This contrasts with southern Taiwan where the drainage

173 system reveals ongoing dynamic adjustment.

174 Because the southward propagation of the arc-continent collision is thought to 175 occur at a rate of $55 \mathrm{~mm} / \mathrm{yr}$, Stolar et al. (2007) estimated that 1.8-2.3 Myr are 176 required to reach topographic steady-state after emergence above the sea level. Due

177 to the space-time equivalence, topographic steady-state becomes apparent at a 178 distance of 100-125 km from the southern tip of Taiwan. At this latitude individual 179 drainage basins yield rapid increase of the uplift of the southern Central Range 180 (Ramsey et al., 2007). However, Whipple (2001) argues that the timescale for the

181 Quaternary climate fluctuations and fast uplift is not enough to achieve topographic 182 steady-state, thus mountainous landscapes of Taiwan have been capable only to 183 adjust to 'mean climatic conditions'. The irregularity of the drainage system and the 184 high asymmetry of the orogen at the Hengchun Peninsula reflect its landscape to be 185 the youngest of the emerging Taiwan orogen.

186 The only geomorphological study carried out over Hengchun's Peninsula (Ramsey, 187 2006) indicates a dynamic drainage system rearrangement suggesting a short 188 duration of the geomorphic response to tectonic/climatic imprint. Ramsey (2006) 189 also suggested a lithological control for the drainage basins by the emergence of 190 Holocene coral reef limestones along the coast (Fig. 2). The uplifted limestone acted 191 as a barrier for sediments sourced from perched drainage basins, hence keeping the 
192 discharge low enough to trap sediments in the upstream part of the drainage system

193 but this hypothesis hardly explains the initial shaping of low reliefs areas.

195 4. Methods

196 4.1. Topographic and Relief analyses

197 Swath averaged-profiles of topography were built across the studied region to 198 report the main landscape characteristics from the Central Range in the north, down

199 to low-elevated areas of the southern Hengchun Peninsula (Fig. 3). Each profile was 200 taken perpendicular to the divide's strike where the mean, maximum and minimum 201 elevations of the DEM (SRTM 90) along an E-W $10 \mathrm{~km}$ window are projected into 202 cross-section planes.

203 In order to track the mean orientations of local relief in the Hengchun Peninsula, we 204 used a 3D analysis approach using a 5x5 m scale DEM (e.g. Ahnert, 1984) collected 205 by the Aerial Survey Office, Forestry Bureau- Taiwan. To carefully map the low-relief 206 areas, we adopted a circular sliding window of $5 \mathrm{~km}$ diameter where the mean local 207 relief (difference between the highest point and lowest point) is reported on the 208 center of this relief grid (Fig. 4).

209 Field campaigns were conducted from 2011 to 2014 to establish a direct control on 210 geomorphological features recognized from the DEM. In particular, areas of 211 potential river capture were investigated to evaluate the possible control by local 212 lithological or artefacts. Overall, field surveys allowed us to improve our 213 understanding of the incision processes in upstream regions in complement to 214 quantitative analyses. 
4.2. Steepness index and concavity index

217 In addition to the two-dimensional topographic analysis of river profiles we 218 estimated the slope-area relationship that is characteristics of erosional processes.

219 The channel slope (S) is linked to the drainage area (A) by an inverse power law 220 such as:

$$
S=k_{S} A^{-\theta} \text { (Eq. 1) }
$$

222 where $\left(\mathrm{k}_{\mathrm{s}}\right)$ and $(\theta)$ correspond to steepness index and concavity index, respectively 223 (Hack, 1957; Flint, 1974; Snyder et al., 2000; Lague and Davy, 2003). If we assume 224 that fluvial erosion follows a detachment-limited erosional pattern, the erosion (E) 225 is governed with a stream power law such as:

$$
E=K A^{m} S^{n} \text { (Eq. 2) }
$$

227 where $K$ represents the erodibility of rocks, $A$ the upstream drainage area and $S$ the 228 local slope (Howard, 1994; Whipple and Tucker, 1999).

229 In the specific case of steady state where E equal uplift rate (U), equation 2 becomes:

$$
S=(U / K)^{1 / n} A^{-m / n} \text { (Eq. 3) }
$$

231 Where $(U / K)^{1 / n}$ and $-m / n$ represent $\mathrm{k}_{\mathrm{s}}$ and $\theta$, respectively. In a log-log plot, $\theta$,

232 which is sensitive to the basin hydrology, corresponds to the slope of the regression

233 line whereas $\mathrm{k}_{\mathrm{s}}$ is the intercept. Both $\mathrm{k}_{\mathrm{s}}$ and $\theta$, are known to be highly sensitive to

234 tectonic uplift (e.g., Snyder et al., 2000). The concavity $\theta$ typically varies in the small

235 range of 0.4 to 0.6 . This enables us to adopt a reference concavity index $\left(\theta_{\text {ref }}\right)$

236 where different stream profiles can be directly compared by a normalized steepness

237 index $\left(\mathrm{k}_{\mathrm{sn}}\right)$ (Wobus et al., 2006; Kirby and Whipple, 2012). We keep in mind that 
238 these parameters are often deduced from an equilibrium stage of river profiles.

239 However for transient cases the response time of rivers may be longer than the

240 tectonic forcing as indicated by the presence of knickpoints in river profiles. In that

241 case, one may consider that knickpoint separates an upstream section in a paleo-

242 equilibrium stage from a downstream oversteepened part in a final equilibrium

243 stage (Whipple and Tucker, 1999).

244 Here, we have adopted the automated method for extraction of steepness and

245 concavity indexes on stream profiles developed by Whipple et al. (2007) on a

246 ArcGIS-Matlab environment that can be freely downloaded at geomorphtools.org.

\section{4.3. Modeling knickpoint retreat}

249 An important point concerning the morphological evolution of Hengchun Peninsula

250 is to evaluate if this landscape is a result of a uniform or more distributed uplift. A

251 uniform uplift would induce a wave of regressive erosion in a radial pattern in the

252 watersheds (Crosby and Whipple, 2006; Berlin and Anderson, 2007). By contrast, a

253 distributed uplift would induce a mixing of wave of erosion, shifting and capture of

254 rivers (e.g., Jackson et al., 1996).

255 To investigate the hypothesis of a wave knickpoint migration, we tested a 256 knickpoint celerity model. The model predicts knickpoints position at each time step 257 (Crosby and Whipple, 2006; Berlin and Anderson, 2007; Loget and Van Den 258 Driessche, 2009; Gallen et al. 2013) such as:

$$
V=d x / d t=C A^{P} \text { (Eq. 4) }
$$


260 where $V$ is upstream knickpoint migration rate, $C$ is a constant dimensional 261 coefficient representing erodibility and efficiency of the knickpoint retreat, $A$ is an 262 upstream area and $p$ is a non-dimensional constant for the power law dependence

263 on a drainage area. We have considered a uniform erodibility at the scale of the 264 basin as suggested by the uniform lithology of the Mutan turbidites.

265 We hypothesized an initial upstream area or a starting point for the knickpoint 266 migration as the converging point of main knickpoints in the basin coupled to the 267 presence of knickpoints in all upstream sub-watersheds. In the absence of data for 268 incision or knickpoint migration rates, we tested two end-member classes of 269 parameters for the modeling that fit with response time around $10^{4}$ to $10^{5}$ years for 270 knickpoint migration. We used the model parameters of Crosby and Whipple, 271 (2006) (hereafter abbreviated CW) with $\mathrm{V}=7.9 \quad 10^{-7} \mathrm{~A}^{1.1125}$ (that favors large 272 upstream area with a low efficiency for knickpoint retreat) and the model of Loget 273 and Van Den Driessche (2009) (hereafter abbreviated LVDD) where V $=10^{-4} \mathrm{~A}^{0.5}$ 274 (that favors small upstream area with a high efficiency for knickpoint retreat). Both 275 models were stopped when the modeled knickpoint reach the farthest knickpoints 276 (KP5).

278 4.4. Asymmetry Factor (AF) observations

279 To highlight the areas with potential captures, we have adopted the non280 dimensional Asymmetry Factor (AF) (Hare and Gardner, 1985): 
282 where, $A_{r}$ represents the drainage area to the right of the main trunk stream looking 283 downstream and $A_{t}$ is the total drainage area. A symmetric catchment with a mean 284 value of $\mathrm{AF}=50$ indicates equal development of the drainage basin both on the right 285 and left side of the basin. Decrease or increase of the AF value indicates the 286 development of asymmetry on either side of the drainage area. Such asymmetry can 287 potentially emphasize an area where one drainage basin through a capture adopted 288 new tributaries. In our AF analyses we targeted small drainage basins along the 289 main divide and coasts, where the $\mathrm{AF}$ is more sensitive to local variances.

\section{5. Results}

2925.1 Topographic and relief analyses

293 The Central Range of Taiwan evolves from a well-organized transverse drainage 294 system that progressively turns southwards into asymmetrical and disordered 295 drainage system stretched over the whole Hengchun Peninsula (Fig. 3). Across the 296 Central Range, the highest elevation on the swath profile (mean, maximum or 297 minimum altitudes) is located near the divide (Fig. 3a). This contrasts with the 298 Hengchun Peninsula where the highest elevation and main divide split in two 299 different eastern and western subdomains and associated divides (Fig. 3b).

300 For instance, the highest domain of the peninsula $(\sim 1000 \mathrm{~m})$ is observed in the 301 Lilong Range that sets close to the western coast. Conversely, the Mutan Ponds in 302 the eastern part of the peninsula is lower $(\sim 400 \mathrm{~m})$ but are located along the main 303 divide (Fig. 3b). 
304 Relief map (Fig. 4) shows that the maximum local relief (between $400 \mathrm{~m}$ and $800 \mathrm{~m}$ )

305 is located in the northwest part of the Hengchun Peninsula, in the Lilong Range. The

306 southern and eastern parts of the peninsula are characterized by an alternation of

307 moderate (between $250 \mathrm{~m}$ and $400 \mathrm{~m}$ ) and low reliefs (lower than $250 \mathrm{~m}$ ). Figure 4

308 further reveals that the both low and high relief domains are oriented N-S.

309 The main drainage basins are Fengkang, Sizhong and Gutou (Fig. 5). They drain over

$31060 \%$ of the peninsula's surface (of the area of $3 \times 10^{2} \mathrm{~km}^{2}$ ), while over 20 basins

311 distributed along the coasts have drainage areas in the 2 to $5 \mathrm{~km}^{2}$ range with only

312 three basins of $\sim 1 \mathrm{~km}^{2}$ and two of $\sim 20 \mathrm{~km}^{2}$. The significant feature is that

313 headwaters of the two main basins (Fengkang and Sizhong) are positioned in the

314 low-relief area of the Mutan Ponds, while their outlets set at the high-relief region in

315 vicinity of the Lilong Range.

316 They drain northern and central Hengchun Peninsula and therefore are the most

317 suitable targets to examine the fluvial network response of the landscape to the base

318 level change. Gutou drainage basin at the southern part of the peninsula flows into

319 the Pacific Ocean to the east. Its whole basin is situated in the low-relief zone and

320 together with Mutan Ponds in the north form the youngest landscape of the

321 emerging wedge (Fig. 4). Headwaters of the Fengkang, Sizhong and Gutou basins

322 begin at comparable elevations of 350-400 meters, but only Sizhong and Fengkang

323 expose apparent shrinkage of the relict landscape.

324 Fengkang basin channels expose knickpoints in the upstream area. This contrasts

325 with the Sizhong basin that is characterized by a more extensive distribution of the

326 knickpoints, probably reflecting a more dynamic response to the relative base level 
327 fall. In the Gutou basin, knickpoints are apparent only in the vicinity of the drainage

328 divide (Fig. 5). East of the main divide, a number of knickpoints reveal advancing

329 fluvial processes, however their irregular vertical distribution suggest different 330 origin. Some of knickpoints located close to the main divide are related to capture 331 events of the Sizhong basin at the Mutan Ponds area.

\section{5.2. Long river profiles, steepness and concavity indices}

334 River profiles are commonly used to infer the uplift pattern in active tectonic area 335 (Snyder et al., 2000; Kirby and Whipple, 2001; Kirby and Whipple, 2012). We 336 extracted the main profiles of Fengkang, Sizhong and Gutou (trunk and tributaries)

337 (Fig. 6). One particular feature of these basins is that headwaters of main trunks are 338 located at low-elevation close to the Mutan ponds and are thus at lower altitudes 339 than their tributaries. None of three basins presents full graded or concave up 340 profiles arguing for a transient stage. They present numerous knickpoints and

341 knickzones that are located in the upstream part of the trunks and in the tributaries

342 that join them at a maximum distance of 10-15 km from the headwater. Knickpoints

343 are located at an altitude of about $300 \mathrm{~m}$ in the Fengkang basin, between 200 and

$344500 \mathrm{~m}$ for Sizhong basin, and between 200 and $400 \mathrm{~m}$ for Gutou basin.

345 The slope-area relationship for Fengkang, Sizhong and Gutou main trunks show the 346 same pattern with some remarkable breaks in regression lines corresponding to the 347 position of knickpoints (Fig. 6). $\theta$ values for Fengkang river are 0.42 and 0.43 348 upstream and downstream of the break, respectively. We choose a value for $\theta_{\text {ref }}$ of

3490.45 consistent with previous works on Taiwan (Wobus et al., 2006). This $\theta_{r e f}$ value 
350 corresponds to $\mathrm{k}_{\mathrm{sn}}$ values of 7.19 and 33.4 upstream and downstream of the break,

351 respectively. This kind of pattern with a break in the slope-area relationship and a

352 sudden rise of $\mathrm{k}_{\mathrm{sn}}$ values upstream may be interpreted as a transient profile due to

353 an increase of uplift rate (e.g., Whipple et al., 2013). We obtained similar values for

354 Sizhong's $k_{s n}$ (9.52 to 30) but the increase is lower toward the south for Gutou basin

355 (11.3 to 16.4). We also calculated $\mathrm{k}_{\mathrm{sn}}$ values at the scale of the Hengchun Peninsula

356 with the auto-ksn tool developed by Whipple et al. (2007) that allows to do

357 regression over a specified moving window (here $0.5 \mathrm{~km}$ ) (Fig. 7). Results obtained

358 confirm the pattern observed with relief maps. Highest values of $k_{s n}(60-200)$ are

359 located in northwest part whereas lowest values (0-15) are located in the southern

360 part and in the Mutan Ponds. With this analysis we confirm that $\mathrm{k}_{\mathrm{sn}}$ values are lower

361 in the upstream part than downstream for Fengkang, Sizhong and Gutou basins.

362 This trend is not observed on rivers that flow toward the east. This reflects the fact

363 that inherited low-relief domains also characterized low $\mathrm{k}_{\mathrm{sn}}$ values are confined on

364 the western side of the main divide and are incised with rivers flowing toward the 365 west.

367 5.3. Modeling knickpoint retreat: Is there a wave of regressive erosion in the Hengchun 368 Peninsula?

369 The only basin where $\mathrm{k}_{\mathrm{sn}}$ in the main trunk is higher or in the same order than

370 tributaries is the Sizhong basin and could correspond to a local wave of regressive 371 erosion. 
372 If one examines the map distribution of knickpoints on the Hengchun Peninsula, 373 they do not appear to follow a full radial pattern in the different watershed of the 374 peninsula except for the Sizhong basin (Fig. 5). We further notice that $\mathrm{k}_{\text {sn }}$ in main 375 trunks are not statistically higher than their tributaries (Fig. 7) as commonly 376 expected for a wave of knickpoint migration (Wobus et al, 2006). Results of 377 knickpoint migration modelling reveal that none of two end-member models can fit 378 both west and east sub-catchments of Shizong (Fig. 8). In the west sub-catchment, 379 the celerity model derived from the parameters used in CW model fits better the 380 position of the five current knickpoints than those derived from LVDD model. The 381 position of three knickpoints is well reproduced and the two others do not exceed 1

$382 \mathrm{~km}$ of misfit assuming CW model for a time duration of $17 \mathrm{Ky}$. With the LVDD model 383 only one knickpoint is reproduced and four with misfit higher than $1 \mathrm{~km}$ for a time 384 duration of $36 \mathrm{ky}$. In the east sub-catchment, the LVDD model well reproduced the 385 position of one knickpoint and the other one with error of more than $1 \mathrm{~km}$. In 386 contrast, the CW model reproduces both knickpoints within an error of more than 1 $387 \mathrm{~km}$ and less than $1 \mathrm{~km}$, respectively.

388 Two conclusions arise from the quantitative modeling of knickpoint retreat. First, if 389 our starting point of knickpoint migration is valid, then the response time according 390 to $10^{4}-10^{5}$ celerity parameters can be estimated to about $17 \mathrm{Ky}$ (according to the 391 best fit model) in the west sub-catchment of Sizhong. In the Hengchun Peninsula, a 392 wave of knickpoints migration can be observed but is limited to a local scale (here $393 \sim 20 \mathrm{~km}^{2}$ ) that excludes a uniform uplift of the whole peninsula. Second, knickpoints 394 migration both in the eastern and western sub-catchments cannot be reproduced 
395 with a simple celerity modeling. By testing two end-member models that are 396 assumed to reproduce the whole range of knickpoint regressive erosion processes,

397 we rule out an incomplete parametric study. We rather suspect changes in the 398 upstream drainage area that can be explained by a process of capture of one sub-

399 catchment by another one. This piracy process could explain why the altitude of the 400 graded part of each trunk profile, for west and east sub-catchments, is different.

\section{5.2. River capture}

403 A significant part of knickpoints cannot be explained by a wave of regressive erosion 404 moving upstream and incising an uplifting inherited landscape. The observation of 405 capture points instead is remarkable in the Hengchun Peninsula. This argues for 406 drainage reorganization caused by piracy or capture effects, especially in the

407 Sizhong basin where this mechanism is probably the most significant. For example, 408 a number capture points can be observed along the main divide suggesting its

409 westward movement. Fieldwork investigations carried out along the main drainage 410 divide confirm very active regressive erosion upstream of the eastern drainage 411 basins (Fig. 9).

412 Figure 10 shows a good example where part of the Sizhong basin was captured by 413 eastward draining tributary of the Xuhai channel. The knickpoint observed along 414 the western tributary is very likely a capture point as indicated by the abrupt 415 change of flows above the knickpoints and the large inflexion of the divide (Fig. 10b, 416 red arrow). 
417 The upstream reaches of Xuhai basin display an asymmetrical pattern (Fig. 10c).

418 Using the shape of the main drainage divide, flow direction of the tributaries

419 together with assumption that knickpoints are actually capture points, we obtained

420 a possible drainage arrangement before the capture with a symmetrical basin model

421 (Fig. 10d).

422 The regressive erosion that led to river capture is not only observed at the main

423 drainage divide. For instance, the 'pre-capture' geometry is seen in the vicinity of

424 the downstream of the Sizhong River (Fig. 11). Zhushe tributary of the Baoli River

425 flows nearly 100 meters above the meander of the Sizhong main channel. An outside

426 band of the Sizhong meander undercuts a hill slope removing western tributaries of

427 the Baoli channel. This reflects that continuous regressive erosion is currently

428 triggering a capture by merging the upper part of the Baoli basin with the Sizhong

429 basin. This will result in the migration of the drainage divide toward the east. A very

430 low Asymmetry Factor $(\mathrm{AF}=20)$ of the central and upper part of the Baoli channel

431 confirms the role of capture dynamics.

\section{6. Discussion}

434 The geomorphological analysis performed on the Hengchun Peninsula argues for a 435 transient stage of the landscape evolution of the southern Taiwan (Ramsey et al., 436 2007; Stolar et al., 2007). The presence of preserved low reliefs may be classically 437 attributed to a change of uplift not yet counterbalanced by fluvial erosion (e.g., 438 Davis, 1989). The normalized steepness indexes of rivers $\left(\mathrm{k}_{\mathrm{sn}}\right)$ are also strongly 439 correlated to relief maps (Fig. 4 and 7) with an increase of $k_{s n}$ downstream of 
440 knickpoints in all main trunks (Fig. 6). In steady-state conditions, high and low

441 values of $k_{s n}$ represent high uplift zones and low uplift zones, respectively (Snyder et

442 al., 2000). $\mathrm{k}_{\mathrm{sn}}$ values show a sudden increase in slope-area relationships along river

443 profiles that reflect an increase of the uplift rate in transient conditions (e.g.,

444 Whipple et al., 2013). This is well documented for Fengkang, Sizhong and Gutou

445 rivers (Fig. 6). Both geomorphic markers- low reliefs and $\mathrm{k}_{\mathrm{sn}}$ distribution maps

446 reflect a transient landscape evolution consecutive to an increase of the uplift rate.

447 However, the location of this relict landscape seems confined to the N-S trending

448 axial part of the peninsula, which is bounded by knickpoints. This questions the

449 scenario of a simple rejuvenation of an antecedent drainage system.

450 Based on a celerity modeling of knickpoint retreat, we show that only upstream

451 Sizhong area can be explained as the result of a wave of regressive erosion through

452 the peninsula (Fig. 8). On the other hand, we have documented numerous capture

453 points arguing for a drainage rearrangement of the drainage system during the last

454 uplift stage (Fig. 10). Thus, the landscape of the Hengchun Peninsula evolves as

455 result of coupling effect of uplift-wave of regressive erosion and drainage captures.

456 We propose to correlate this pattern to the emergence of the southern Taiwan

457 (Suppe, 1981; Pelletier and Stephan, 1986; Liew and Lin, 1987; Ramsey at al., 2007;

458 Stolar et al., 2007). In this case, the drainage rearrangement is no related to a

459 'rejuvenation' of the topography, but rather to a birth of a new landscape. The

460 studied landscape is recent because marine deposits younger than 100 ky are today

461 uplifted in the southern part of the peninsula (Fig. 2). Holocene coral reefs indicate a

462 surface uplift up to 30-40 m for the last $10 \mathrm{ky}$ (Peng et al., 1977; Wang and Burnett, 
463 1990) whereas Hengchun limestone suggests a surface uplift around 100-200 m for

464 the last 100 ky (Cheng and Huang, 1975; Chen and Lee, 1990). Assuming the

465 southward propagating model, the ancient coastline and outlet of drainage systems

466 was positioned between the present low-relief of Mutan Ponds and the current

467 coastline. Consequently, before this emergence in Late Pleistocene times, the low

468 relief of Mutan Ponds should be in a direct continuation with the coastline. The

469 landscape during this initial period was likely composed by reduced EW-directed

470 transverse streams, and by the N-S drainage in the Mutan Ponds area at the

471 southern limit of the island (Fig. 12a). The presence of current low reliefs with a N-S

472 trend in the Gutou drainage basin (Fig. 4) argues for such a physiography during

473 this pre-emergence period. The post 100 ky emergence of the submarine

474 morphology resulted in an asymmetrical arrangement of the drainage pattern. The

475 sudden emersion triggers a wave of regressive erosion upstream in drainage basins

476 that were connected to the newly emerged prism. We have documented this wave of

477 regressive erosion in western drainage basins especially for the Sizhong basin. This

478 kind of pattern where transverse drainages coexist with or capture inherited

479 longitudinal paleo-drainages at the termination of tectonic emerging structures has

480 been described in growing folds (e.g. Ramsey et al., 2008).

481 One other possible effect of this emerged asymmetric area to the west is the shift of

482 the drainage divide towards the center of the peninsula, triggering the isolation of

483 the initial low reliefs (Mutan Ponds) (Fig. 12b). Such scenario could explain the

484 current inflection of the drainage divide inside the Hengchun Peninsula. 
485 Then, the continuation of regressive erosion of western catchments (Fengkang and

486 Sizhong) will eventually capture these low reliefs. If we consider an endoreic system

487 in Mutan Ponds due to lake deposits in Holocene times up to 2 ky (Lee et al., 2010),

488 the capture event in the upstream part of Fengkang and Sizhong could be only few

489 thousand years old. This can explain why we observe some misfits between eastern

490 and western sub-catchments in Sizhong basin.

491 As the surface uplift propagates southwards, the main drainage divide remained at

492 the eastern flank of the peninsula. The continuous uplift of the low-relief Mutan

493 Ponds increases incision from the east-draining basins. This wave of regressive

494 erosion leads to the second stage of captures. As a result, the eastern basins enlarge

495 their areas due to the west-draining catchments and consequently move the main

496 divide to the west (Fig. 12c, red arrows). Documented captures of the east-draining

497 basins as well as potential points of future piracies substantially support this

498 concept (Fig. 10 and 11). However, the locations of the high and low reliefs as well

499 as the distribution of normalized steepness index $\mathrm{k}_{\mathrm{sn}}$ suggest the western low-relief

500 terrains to be missing (Fig. 4). It can be related to a submarine topography west to

501 the Hengchun Peninsula where the slopes are too steep to emerge a vast low-relief

502 area or due to fast uplifts of the narrow accretionary wedge generated submarine

503 landslides removing the west flank of the low-relief areas.

504 In summary, the model describing the evolution from the emerging submarine

505 surface to the birth of a new landscape support the transient character of the

506 Hengchun Peninsula. The drainage rearrangement pattern reveals localized waves

507 of knickpoints retreat and shrinkage of the relict landscape as a coherent process 
508 (Fig. 13). One of the significant assessments of this study is that the landscapes of

509 the emerging orogens even in the short time span appear to be justified. Our

510 geomorphological analysis and proposed evolutional model does not allow

511 distinguishing between the different modes of crustal accretion proposed for the

512 Central Range of Taiwan further North: underplating of a subducted crust (Simoes

513 et al., 2007) or ductile flow in the deep crust (Yamato et al., 2009). However, our

514 data and results support a lack of distributed shortening/thrusting across the

515 peninsula, in the southern Central Range. This suggests the region is uplifting as a

516 crustal block, with shortening being accommodated by aseismic deformation in the

517 deeper crust. This might support the onset of crustal shortening below the shallow

518 accretionary wedge as proposed from nearby offshore observations (McIntosh et al., 519 2013).

520

\section{7. Conclusions}

522 In this study, we focused on the emerging topographic ridge at the southernmost tip 523 of Taiwan orogen, which is the onboard continuity of the offshore accretionary 524 prism. The extraction of geomorphic parameters shows a transient nature of the 525 topography of the Hengchun Peninsula in particular attested by knickpoints 526 distribution and steepness index of rivers. However, we demonstrate that a simple 527 model of regressive erosion following uplift as a rejuvenation of the topography is 528 unlikely at the scale of the entire Peninsula. Knickpoint celerity modeling shows that 529 it is restrained to the upstream part of the Sizhong basin. On the other hand, the 530 current asymmetrical drainage system, linked to a main divide flanked on the 
531 eastern side of the Peninsula and where N-S low reliefs (Mutan ponds area) are

532 pinned, is currently affected by numerous capture processes. This indicates a 533 progressive rearrangement of the drainage system confirming the transient nature

534 of the topography. We have proposed an evolutional model of the Hengchun

535 Peninsula that can explained: (i) how from an antecedent N-S drainage (due to a

536 paleo-northern coastline) it is possible to generate low relief and offset divide (ii)

537 then uplifted and captured by E-W transverse drainages (due to a progressive

538 emergence and shifting coastline). In other words, the Hengchun Peninsula's

539 topography results from a mixing between rejuvenation and drainage

540 reorganization due to the emergence of the southern domain of Taiwan. The scale of

541 this landscape perturbation and the lack of localized tectonic structures argue for an

542 uplifted crustal block origin.

543

544 Acknowledgments.

545 This study was supported by National Science Council, Taiwan (NSC 101-2116-M-

546 008-006、NSC 102-2116-M-008 -003、MOST 103-2116-M-008-024).

547

548

549 Bibliography.

550

551 Ahnert, F., 1984. Local relief and the height limits of mountain ranges. American J. $552 \quad$ Science, $284,1035-1055$. 
553 Attal, M., Tucker, G.E., Whittaker, A.C., Cowie, P.A., Roberts, G.P., 2008. Modeling

554 fluvial incision and transient landscape evolution: Influence of dynamic channel

555 adjustment. Journal of Geophysical Research, 113, F03013.

556 Berlin, M.M., Anderson, R.S., 2007. Modeling of knickpoint retreat on the Roan

557 Plateau, western Colorado. Journal of Geophysical Research- Earth Surface, 112,

$558 \quad$ F03S06.

559 Bishop, P., Hoey, T.B., Jansen, J.D., Artza, I.L., 2005. Knickpoint recession rate and

560 catchment area: the case of uplifted rivers in eastern Scotland. Earth Surface

$561 \quad$ Processes and Landforms 30, 767-778.

562 Burbank, D.W., 2002. Rates of erosion and their implications for exhumation. $563 \quad$ Mineralogical Magazine, 66, 25-52.

564 Chen Y.-G., Liu, T.-K., 1993. Holocene radiocarbon dates in Hengchun Peninsula and 565 their neotectonic implications. Journal of the Geological Society of China. 36(4), $566 \quad 457-479$.

567 Chen W.-S., Lee W.-C., 1990. Reconsideration of the stratigraphy of the western $568 \quad$ Hengchun Hill. Geology, 10, 2, 127-140.

569 Cheng Y.-M., Huang C.-Y., 1975. Biostratigraphic study in the west Hengchun hill. $570 \quad$ Acta Geol. Taiwanica, 18, 49-59.

571 Craddock, W.H., Kirby, E., Harkins, N.W., Zhang, H., Shi, X., Liu, J., 2010. Rapid fluvial 572 incision along the Yellow River during headward basin integration. Nature $573 \quad$ Geoscience, 3(3), 209-213. 
574 Crosby, B.T., Whipple, K.X., 2006. Knickpoint initiation and distribution within

575 fluvial networks: 236 waterfalls in the Waipaoa River, North Island, New $576 \quad$ Zealand. Geomorphology, 82, 16-38.

577 Davis, W. M., 1989. The geographical cycle. Geogr. J., 14, 481 - 504.

578 Flint, J.J., 1974. Stream gradient as a function of order, magnitude, and discharge. $579 \quad$ Water Resources Research, 10, 969-973.

580 Fuller, C.W., Willett, S.D., Fisher, D., Lu, C.-Y., 2006. A thermomechanical wedge 581 model of Taiwan constrained by fission-track thermochronometry. 582 Tectonophysics, 425, 1-24.

583 Gallen, S.F., Wegmann, K.W., DelWayne R.B., 2013. Miocene rejuvenation of 584 topographic relief in the southern Appalachians. GSA Today, 23, 2.

585 Garcia-Castellanos, D., 2006. Long-term evolution of tectonic lakes: Climatic controls 586 on the development of internally drained basins. Society, 2398(17), 283-294.

587 Giletycz, S.J., Chang, C.-P., Huang, C.-C., 2012. Geological structure as a crucial factor 588 facilitating the occurrence of typhoon-triggered landslides: Case from Hsiaolin 589 Village, 2009 Typhoon Morakot. Western Pacific Earth Sciences, 12, 1, 21-38.

590 Hack, J.T., 1957. Studies on longitudinal stream profiles in Virginia and Maryland. 591 U.S. Geological Survey Professional Paper, 294-B, 97. 
592 Hare, P.H., Gardner T.W., 1985. Geomorphic indicators of vertical neotectonism 593 along the converging plate margins, Nicoya Peninsula, Costa Rica. Tectonic $594 \quad$ Geomorphology, 4, 75-104.

595 Howard, A., 1994. A detachment-limited model of drainage basin evolution. Water $596 \quad$ Resources Research, 30(7), 2261-2285.

597 Jackson, J., Norris, R., Youngson J., 1996. The structural evolution of active fault and 598 fold systems in central Otago, New Zealand: evidence revealed by drainage 599 patterns. Journal of Structural Geology, 18, 2-3.

600 Kirby, E., Whipple, K.X., 2001. Quantifying differential rock-uplift rates via stream 601 profile analysis. Geology, 29, 415-418.

602 Kirby, E., Whipple, K.X., 2012. Expression of active tectonics in erosional landscapes. 603 Journal of Structural Geology, 44, 54-75.

604 Lague, D., Davy, P., 2003. Constrains on the long-term colluvial erosion law by 605 analysing slope-area relationship at various tectonic uplift rates in the Siwalik 606 Hills (Nepal). Journal of Geophysical Research, 108(B2), 2129.

607 Lee, C.-Y., Liew, P.-M., Lee, T.-Q., 2010. Pollen records from southern Taiwan: 608 implications for East Asia summer monsoon variation during the Holocene. The 609 Holocene, 20, 1, 1-9. 
610 Lin, A.-T., Watts, A.B., Hesselbo, S.P., 2003. Cenozoic stratigraphy and subsidence

611 history of the South China Sea margin in the Taiwan region. Basin Res., 15, 453612478.

613 Liew, P.-M., Lin, C.-F., 1987. Holocene tectonic activity of the Hengchun Peninsula as 614 evidenced by the deformation of marine terraces. Memoir of the Geological 615 Society of China, 9, 241-259.

616 Loget, N., Van Den Driessche, J., 2009. Wave train model for knickpoint migration. $617 \quad$ Geomorphology, 106, 376-382.

618 Loget, N., Davy, P., and Van den Driessche, J., 2006. Mesoscale fluvial erosion 619 parameters deduced from the modeling of the Mediterranean sea-level drop 620 during the Messinian (Late Miocene). Journal of Geophysical Research, 111, $621 \quad$ F03005.

622 Lague, D., Davy P., 2003. Constraints on the long-term colluvial erosion law by 623 analyzing slope-area relationships at various tectonic uplift rates in the 624 Siwaliks Hills (Nepal). Journal of Geophysical Research, 108 (B2), 2129.

625 McIntosh, K.D., Kuochen, H., Van Avendonk, H.J., Lavier, L.L., Wu, F.T., Okaya, D.A., 626 2013. Two-dimensional seismic velocity models of southern Taiwan from 627 TAIGER transects. American Geophysical Union, Fall Meeting, T21G-05.

628 Mesalles, L., Mouthereau, F., Bernet, M., Chang, C-P., Lin, T-S., Fillon, C., Sengelen, X., 629 2014. From submarine continental accretion to arc-continent orogenic 
630 evolution: the thermal record in the Taiwan mountain belt. Geology. doi: 631 doi:10.1130/G35854.1

632 Pelletier, B., Stephan, J.F., 1986. Middle Miocene obduction and late Miocene 633 beginning of collision registered in the Hengchun Peninsula: Geodynamics 634 implications for the evolution of Taiwan. Memoir of the Geological Society of $635 \quad$ China, 7, 301-324.

636 Peng, T.-H., Li, Y.-H., Wu, F.-T., 1977. Tectonic uplift rates of the Taiwan island since 637 the Early Holocene. Memoir of the Geological Society of China, 2, 57-69.

638 Ramsey, L.A., 2006. Topographic evolution of emerging mountain belts. PhD Thesis, 639 not published.

640 Ramsey, L.A., Walker, R.T., Jackson J., 2007. Geomorphic constraints on the active 641 tectonics of the southern Taiwan. Geophysics, 170, 1357-1372.

642 Ramsey, L.A., Walker, R.T., and Jackson, J., 2008. Fold evolution and drainage 643 development in the Zagros mountains of Fars province, SE Iran. Basin Research, $644 \quad 20,23-48$.

645 Roberts, G., White, N. J., 2010. Estimating Uplift Rate Histories from River Profiles 646 using African Examples. Journal of Geophysical Research- Solid Earth, 115. 647 B02406. ISSN 0148-0227

648 Rosenbloom, N.A., Anderson, R.S., 1994. Hillslope and channel evolution in a marine 
649 terraced landscape, Santa Cruz, California. Journal of Geophysical Research, 99 (B7),

$650 \quad 14013-14029$.

651 Siame, L.L., Angelier, J., Chen, R.-F., Godard, V., Derrieux, F., Bourlès, D.L., Braucher, 652 R., 2011. Erosion rates in an active orogen (NE-Taiwan): A confrontation of 653 cosmogenic measurements with river suspended loads. Quaternary $654 \quad$ Geochronology, 6(2), 246-260.

655 Simoes, M., Avouac, J.P., Beyssac, O., Goffe, B., Farley, K.A., Chen, Y.-G., 2007.

656 Mountain building in Taiwan:a thermokinematic model. J. Geophys.Res., 112, $657 \quad$ B11405.

658 Simoes M., Beyssac, 0., Chen, Y.-G., 2012. Late Cenozoic metamorphism and 659 mountain building in Taiwan: A review. Journal of Asian Earth Sciences, 46, $92-$ 660119.

661 Snyder N.P., Whipple, K.X., Tucker, G.E., Merritts, D.J., 2000. Landscape response to 662 tectonic forcing: Digital elevation model analysis of stream profiles in the 663 Mendocino triple junction region, northern California. GSA Bulletin, 112, 12506641263.

665 Stolar, D.B., Willet S.D., Montgomery D.R., 2007. Characterization of topographic 666 steady state in Taiwan. Earth and Planetary Science Letters, 261, 421-431.

667 Suppe, J., 1981. Mechanics of mountain building and metamorphism in Taiwan. 668 Mem. Geol. Soc. China, 4, 67-89. 
669 Walker, R.T., Ramsey, L.A., Jackson, J., 2011. Geomorphic evidence for ancestral 670 drainage patterns in the Zagros Simple Folded Zone and growth of the Iranian 671 plateau. Geological Magazine, 148, 901-910.

672 Wang, C.-H., Burnett, W.C., 1990. Holocene mean uplift rates across an active plate673 collision boundary in Taiwan. Science, 248, 4952, 204-206.

674 Whipple, K.X., Tucker, G.E., 1999. Dynamics of the stream-power river incision 675 model: implications for height limits of mountain ranges, landscape response 676 timescales, and research needs. Journal of Geophysical Research, 104(B8), 677 17661-117674.

678 Whipple, K.X., 2001. Fluvial landscape response time: how plausible is steady-state 679 denudation? American Journal of Science, 301, 313-325.

680 Whipple, K.X., 2004. Bedrock Rivers and the Geomorphology of Active Orogens. 681 Annual Review of Earth and Planetary Sciences, 32(1), 151-185.

682 Whipple K.X., Wobus, C.W., Kirby, K., Crosby, B., Sheehan, D., 2007. New Tools for 683 Quantitative Geomorphology: Extraction and Interpretation of Stream Profiles 684 from Digital Topographic Data. Geological Society of America Annual Meeting $685 \quad$ Course Notes.

686 Whipple K.X., DiBiase R.A., Crosby B.T., 2013. Bedrock rivers. Treatise on 687 Geomorphology. 9, 550-573. 
688 Whittaker, A.C., Cowie, P.A., Attal, M., Tucker, G.E., Roberts, G.P., 2007. Bedrock 689 channel adjustment to tectonic forcing: Implications for predicting river $690 \quad$ incision rates. Geology, 35(2), 103.

691 Willett, S.D., Brandon, M.T., 2002. On steady states in mountain belts. Geology, 30(2), 692175.

693 Willett, S.D., Fisher, D., Fuller, C., En-Chao, Y., Chia-Yu, L., 2003. Erosion rates and 694 orogenic-wedge kinematics in Taiwan inferred from fission-track 695 thermochronometry. Geology, 31(11), 945.

696 Wobus, C.W., Crosby B.T., Whipple, K.X., 2006. Hanging valleys in fluvial systems: 697 Controls on occurrence and implications for landscape evolution. Journal of $698 \quad$ Geophysical Research, 111, F02017.

699 Yamato, P., Mouthereau, F., Burov, E., 2009. Taiwan mountain building: insights from 700 2-D thermomechanical modelling of a rheologically stratified lithosphere, 701 Geophysical Journal International, 176(1), 307-326.

702 Yang, T.-N., Lee, T.-Q., Meyers, P.A., Song, S.-R., Kao, S.-J., Löwemark, L., Chen, R.-F., 703 2011. Variations in monsoonal rainfall over the last 21 kyr inferred from 704 sedimentary organic matter in Tung-Yuan Pond, southern Taiwan. Quaternary $705 \quad$ Science Reviews, 30(23-24), 3413-3422. 

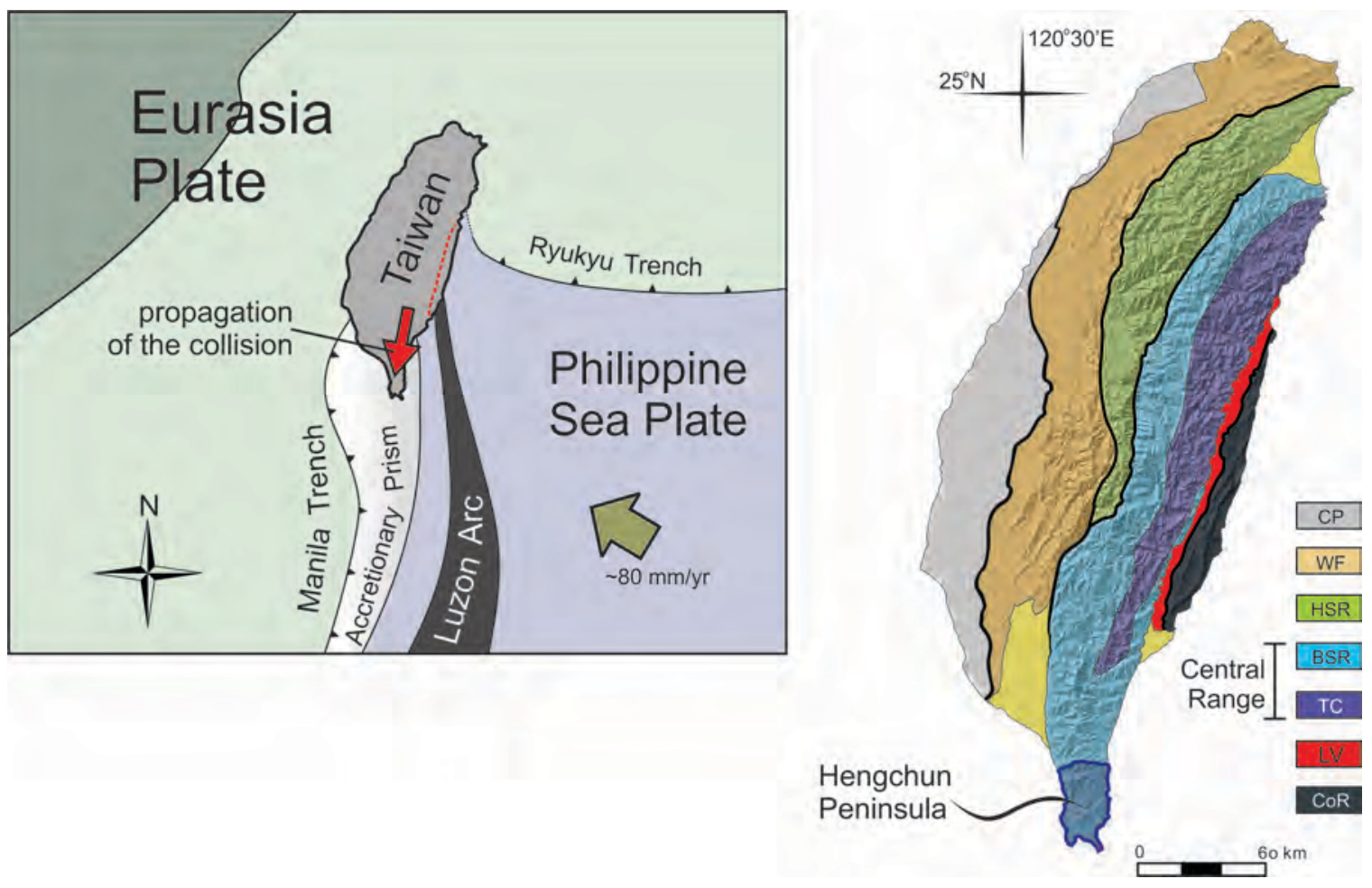

Fig. 1. Geological setting of Taiwan arc-continent collision. Left: map showing the oblique collision between Eurasia and Philippine Sea plates resulting in the progressive emergence of Taiwan orogen towards the south (red arrow). Right: geological provinces of Taiwan: CP- Coastal Plain; WF- Western Foothills; HSRHsuehshan Range; BSR- Backbone Slate Range; TC -Tananao Complex; LVLongitudinal Valley; CoR- Coastal Range. 


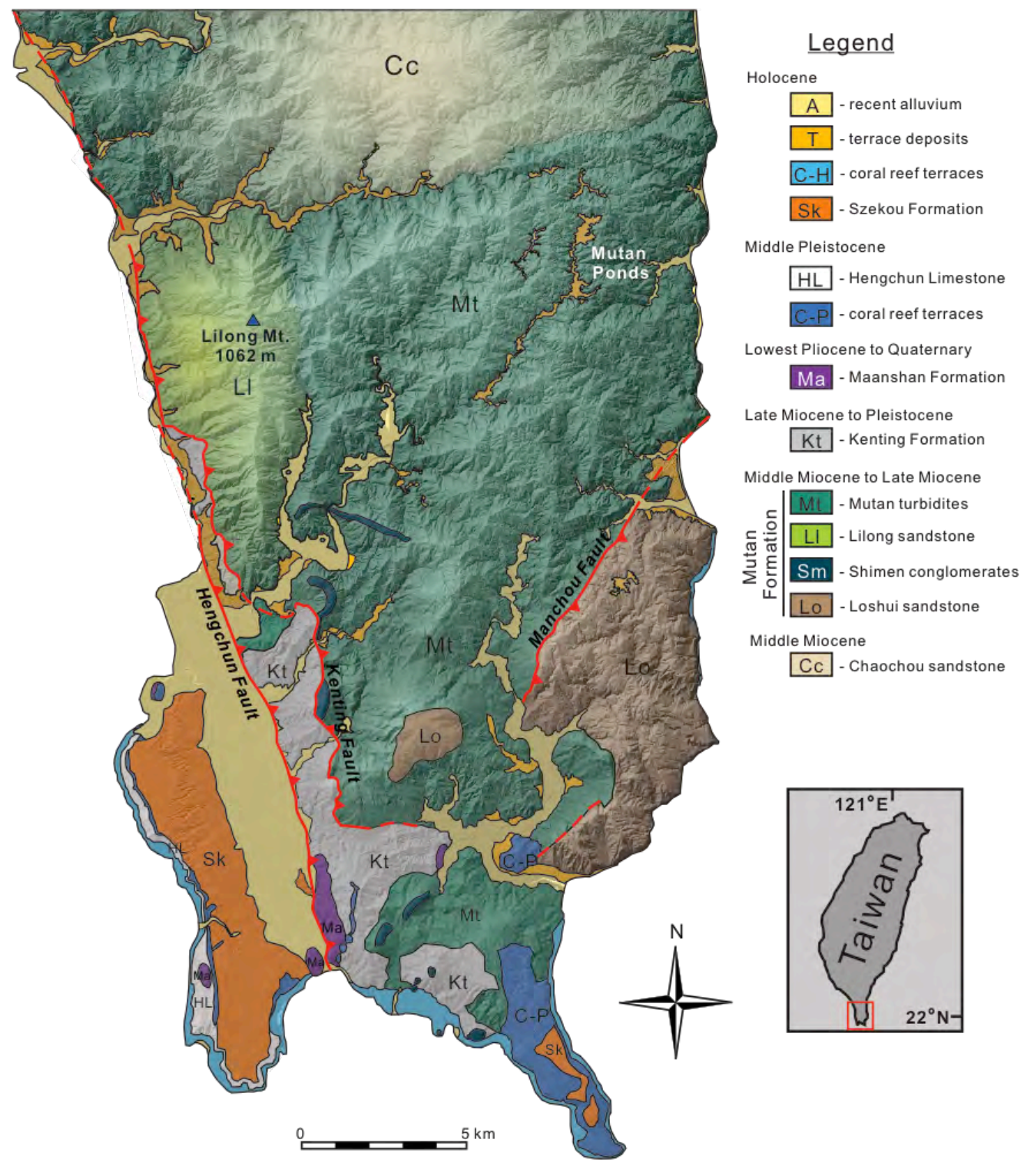

Fig. 2. Geological map of the Hengchun Peninsula (modified after CGS 1989; Chang et al., 2002; Yen, 2003; Chen et al., 2005 and others) 

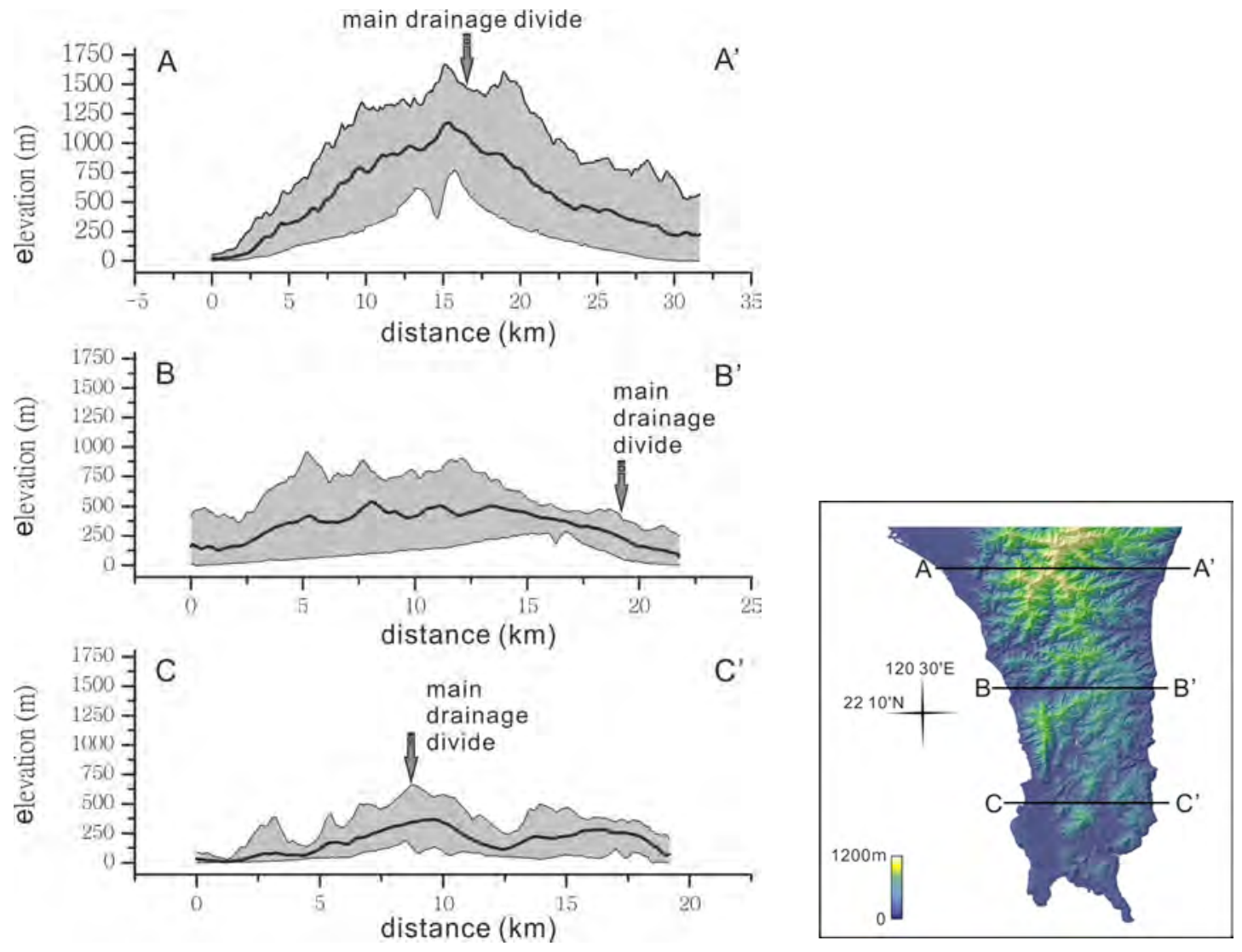

Fig. 3. Swath topography profiles (with $10 \mathrm{~km}$ window) across the southern Central Range, northern and central Hengchun Peninsula, respectively. Each profile shows focal statistics of the highest, mean and the lowest elevation, respectively. The arrows locate the boundary of the main divide. The profile B-B' shows an offset of the main divide and the highest topography point- Lilong Mt. 


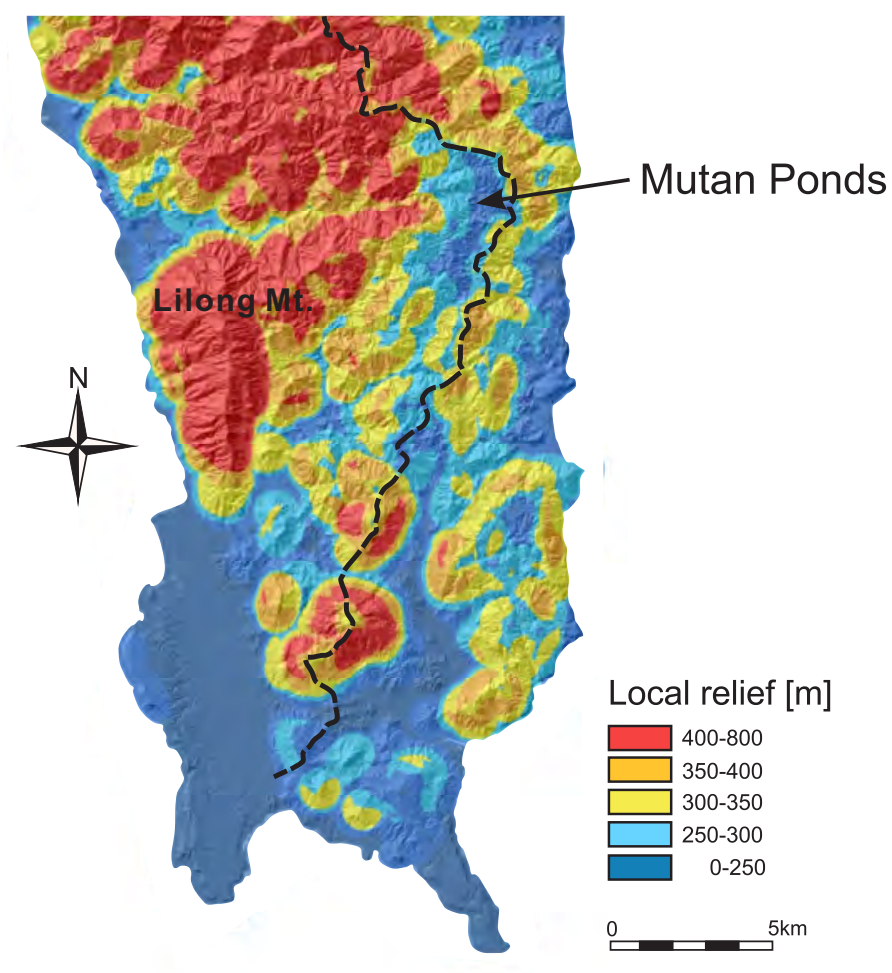

Fig. 4. Relief map of the Hengchun Peninsula (computed with $5 \mathrm{~km}$ sliding window). $\mathrm{N}-\mathrm{S}$ elongated low relief stretch at the eastern part of the peninsula from Mutan Ponds southwards (blue area). Note the main drainage divide (black-dashed line) cutting across the low relief N-S trending area. 


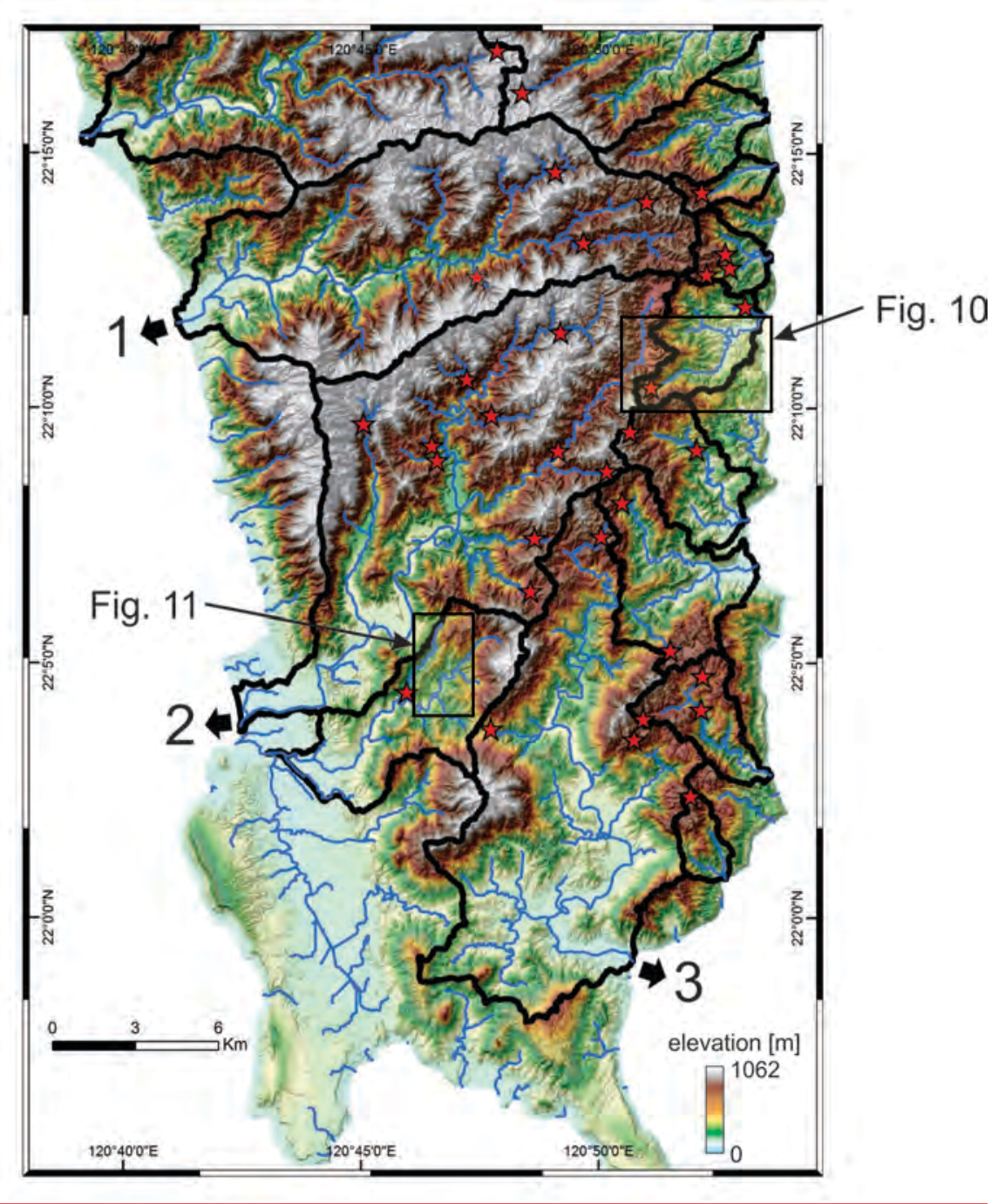

Fig. 5. Drainage basins of the Hengchun Peninsula: 1- Fengkang, 2- Sizhong, 3- Gutou basins. Red stats represent main knickpoints. 

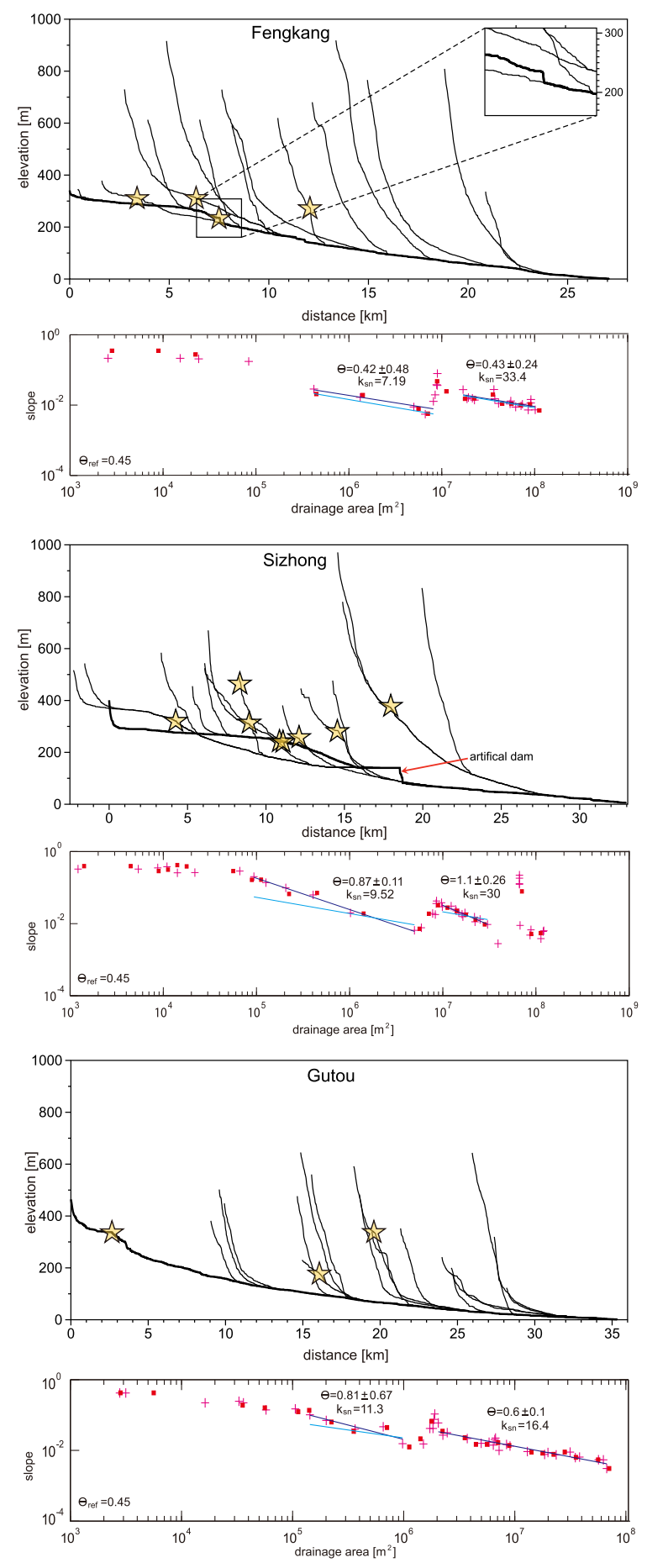

Fig. 6. Long and $\log / \log$ slope-area profiles of the major basins of the Hengchun Peninsula: Fengkang, Sizhong and Gutou. 


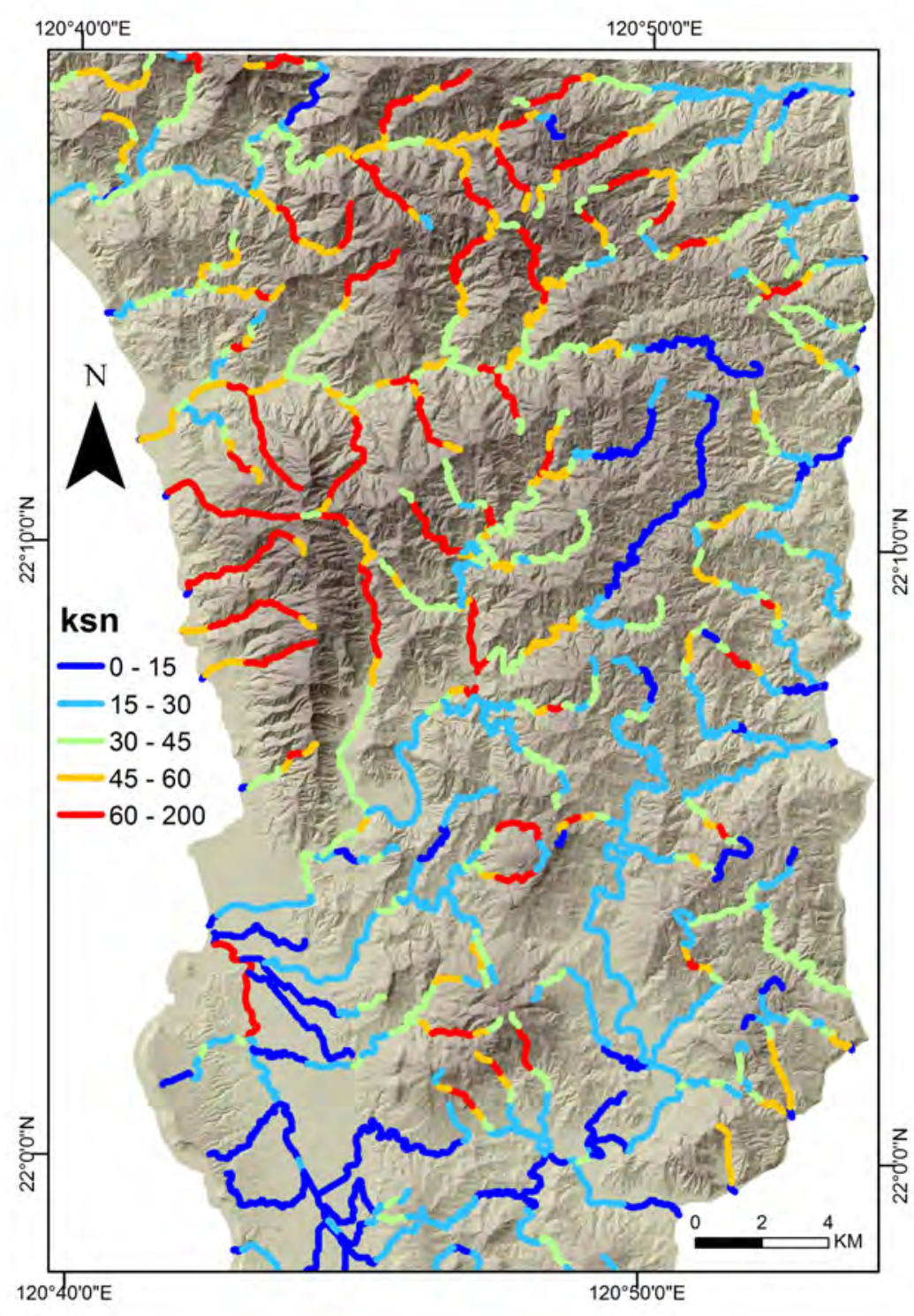

Fig. 7. Normalized steepness index (ksn) of the channels at Hengchun Peninsula 9 (concavity index $\theta_{\text {ref }}$ for all channels is 0.45 ) 


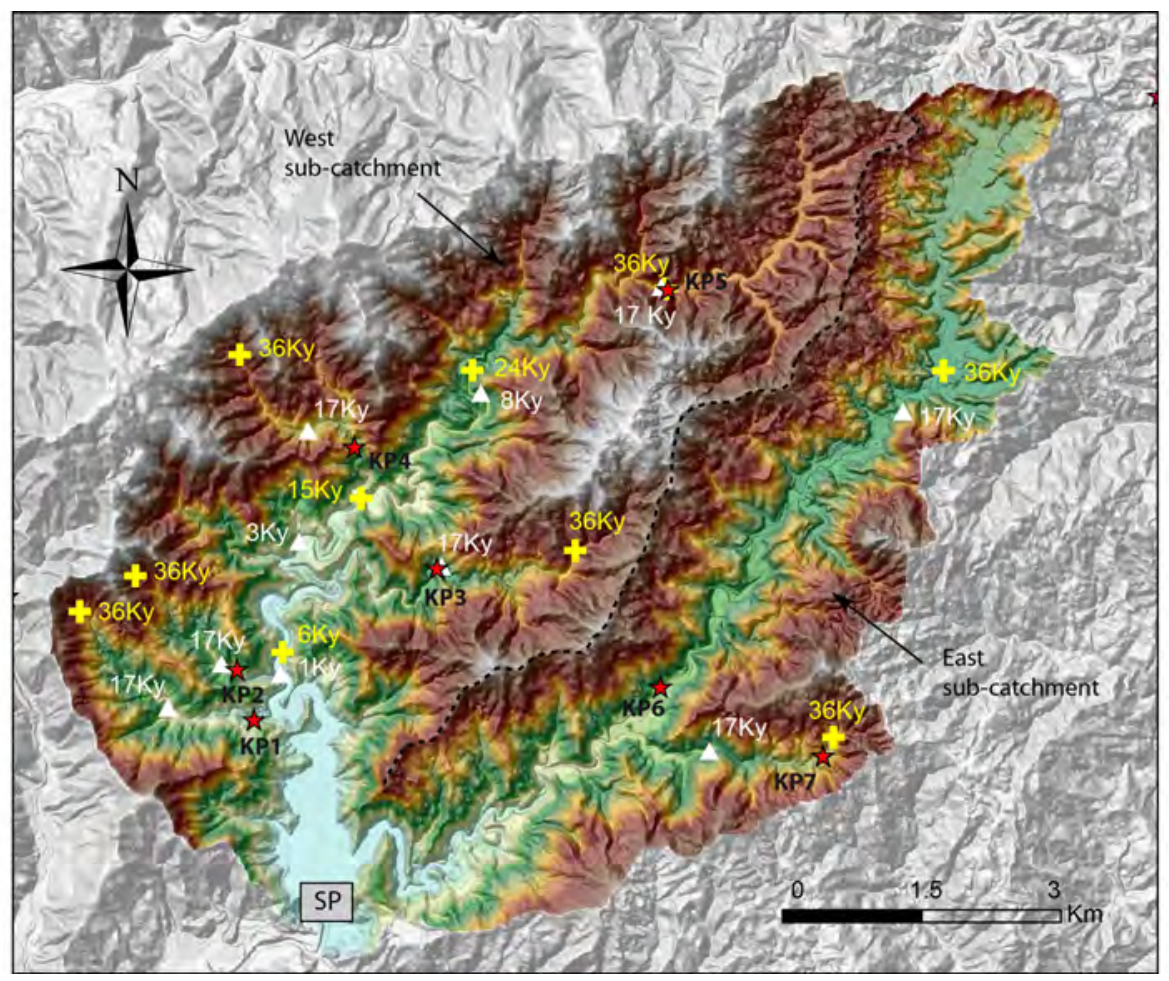

Fig. 8. Celerity modeling of the knickpoints migration in the Sizhong basin (location in Fig. 5 and 13) with two end-members. Red start shows observed knickpoints. White cross represents a modeling of the migration with a celerity modeling where $\mathrm{dx} / \mathrm{dt}=0.0001 \mathrm{~A}^{0.5}$ (Loget and Van Den Driessche, 2009). Blue triangel represents the modeling with $\mathrm{dx} / \mathrm{dt}=0.0000079 \mathrm{~A}^{1.1125}$ (Crosby and Whipple, 2006). Time stopped for all points at $\mathrm{T}=12 \mathrm{ky}$ and $\mathrm{T}=17 \mathrm{ky}$, respectively. SP- represents the starting point. 


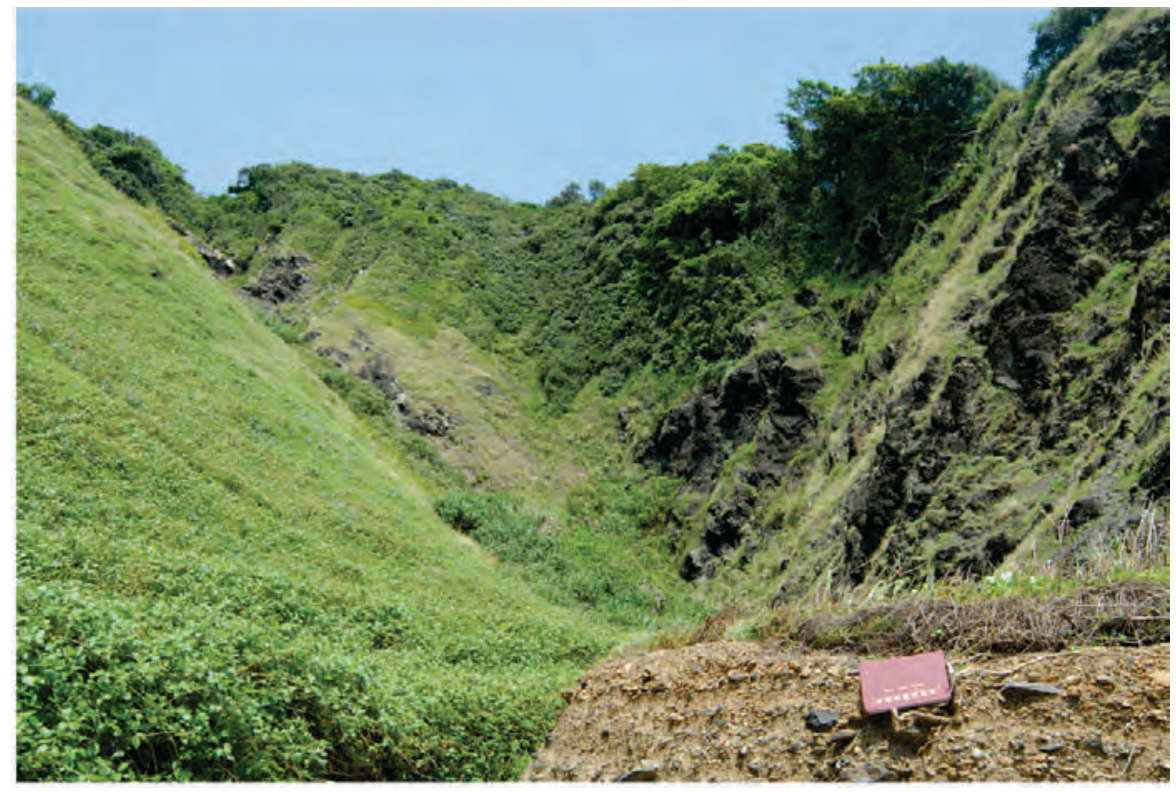

Fig. 9. Photograph looking to the west showing active regressive erosion in the upstream part of a tributary of the Xuhai basin (see location in figure 10). 

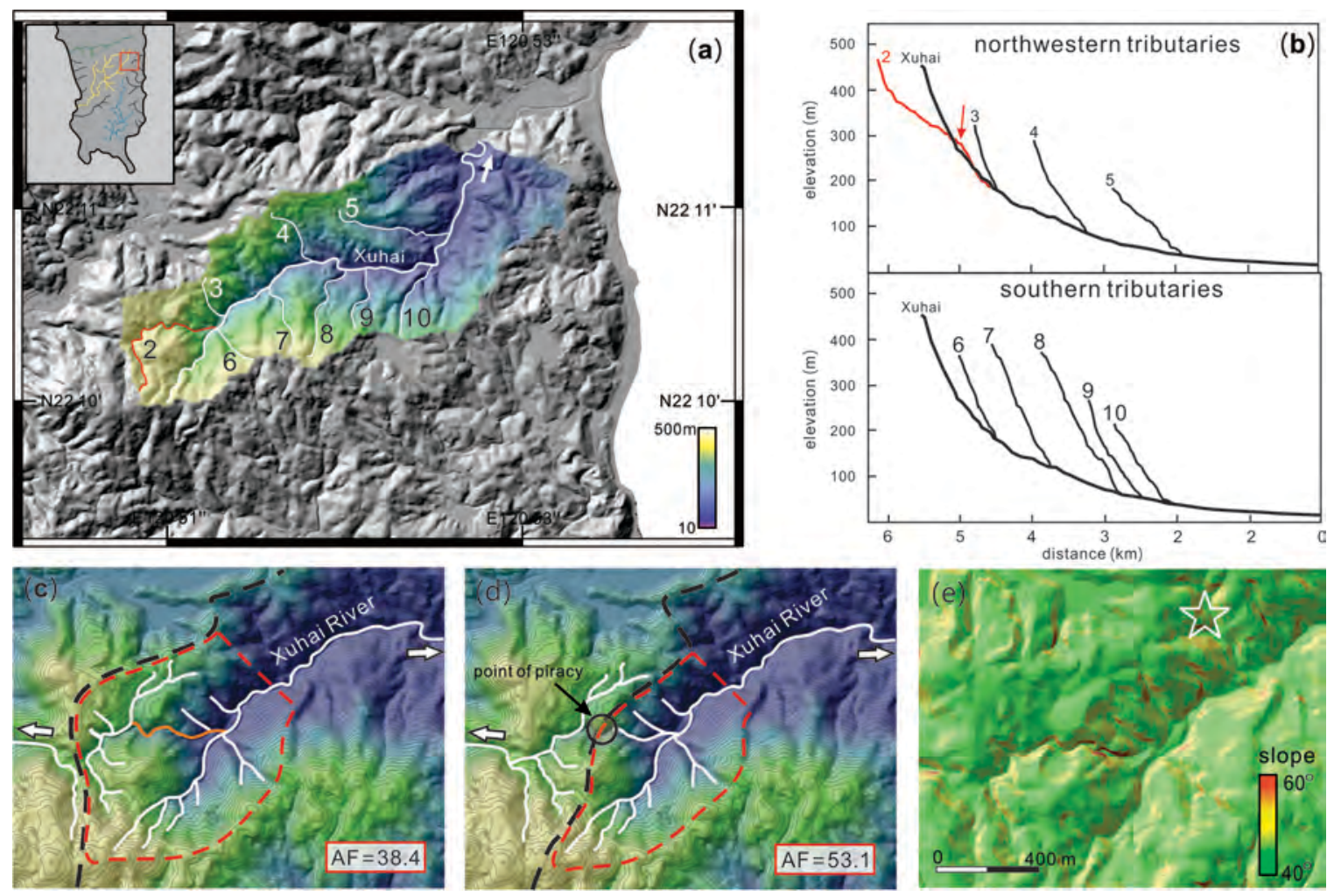

Fig. 10. Capture processes in the western part of the Xuhai basin. a) DEM with drainage of the southern part of the the Xuhai basin showing recent capture channel in orange (location in Fig. 5). (b) Knickpoint of the upper channel (red arrow) indicates the capture point (a). (c) Present setting of the Xuhai upstream. Note the flow direction of the western tributaries and curve of the main drainage divide (black dashed line). (d) Potential scenario before the capture. The Asymmetry Factor (AF) shows almost symmetrical pattern of the Xuhai upstreams. (e) High slope values of the Xuhai channel suggest dynamic incision processes what also fueled the erosion leading to the capture. White star shows the location of the tributary presented in figure 9. 


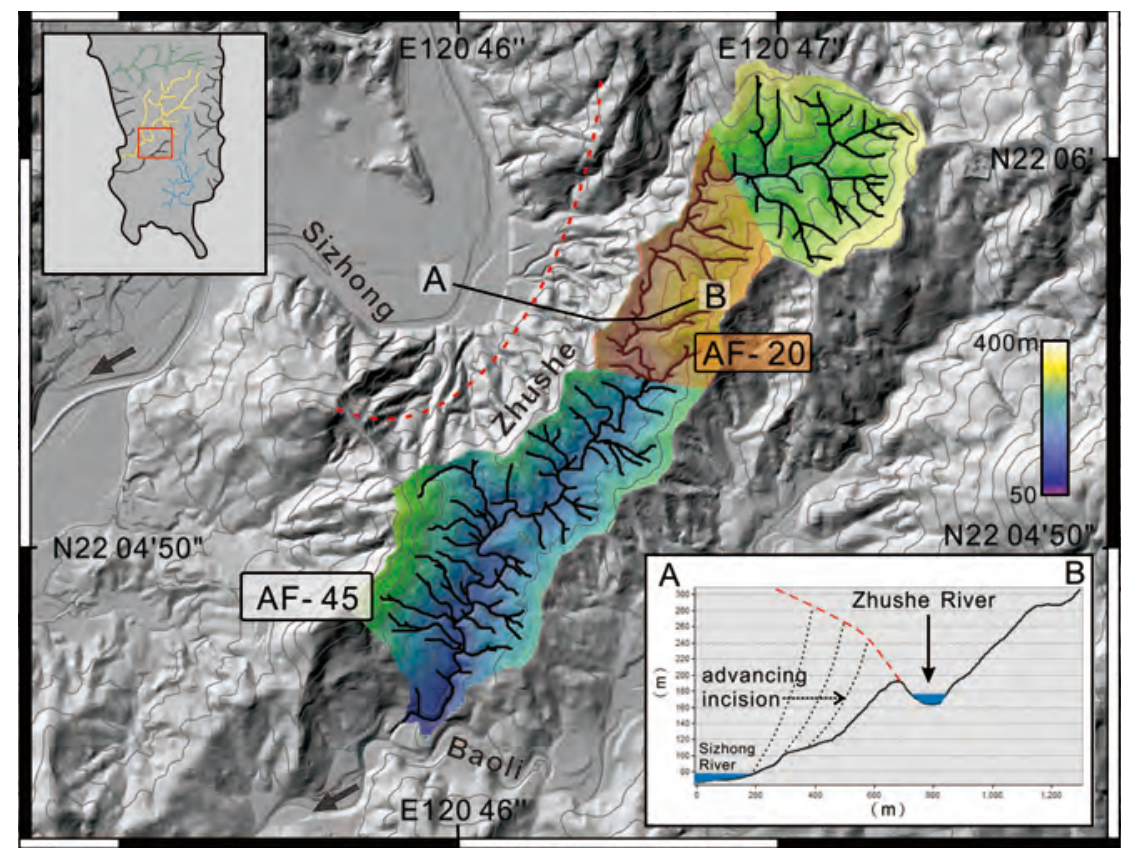

Fig. 11. Capture processes of the Zhushe River (tributary of the Baoli River) by the Sizhong River (location in Fig. 5). Due to progressive erosion of the lower elevated meander of the Sizhong River, the western tributaries of the central-upper part of the Zhushe sub-basin are missing. Note very low Asymmetry Factor (AF) of the marked area (orange) versus whole Zhushe sub-basin. A potential capture become apparent at the marked area in orange. 
a)

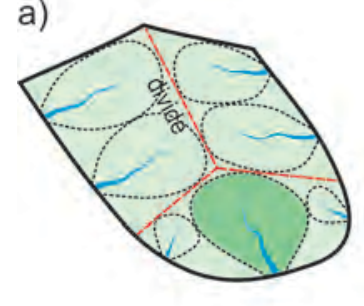

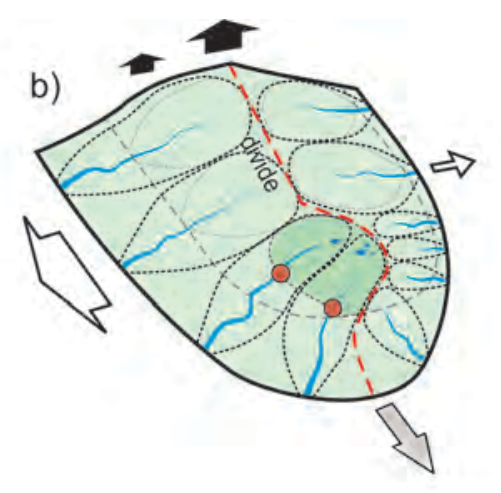

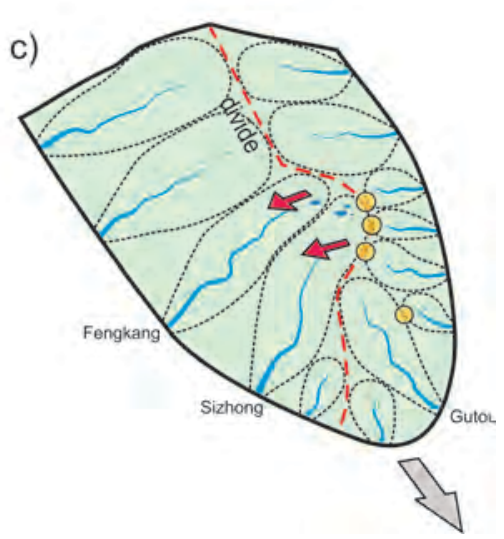

Fig. 12. Evolutionary model of the Hengchun Peninsula. (a) Tip of an emerging orogen develops channels in fan-shape pattern, where N-S drainage is the future Mutan Ponds area. (b) Asymmetric emergence elongates the channels and triggers the isolation of the initial low reliefs- Mutan Ponds. (c) The continuous uplift of the low-relief Mutan Ponds increases incision from the east-draining basins leading to the second stage of captures moving the main divide to the center of the peninsula. 


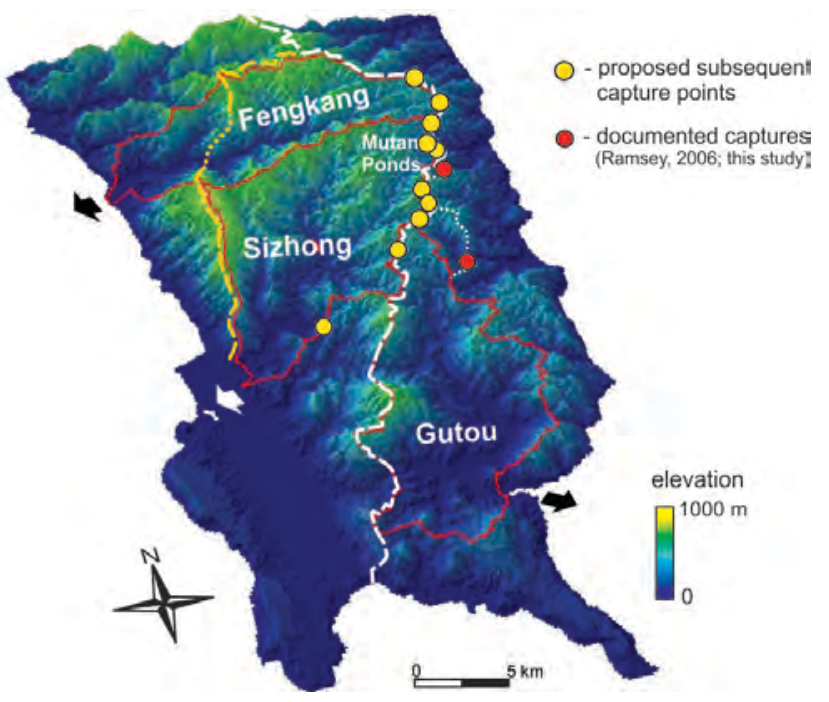

Fig. 13. 3-D view of the Hengchun Peninsula's topography and its main basins. White dashed line shows the main divide, a yellow line shows highest topography ridge. A dotted yellow line shows the break of the highest topography ridge. 